\title{
The Staff as a Symbol of Spiritual Guidance for Individuation
}

\author{
So, Byung Hea*
}

\begin{abstract}
$<$ Abstract $>$
The purpose of this study was to analyze the symbolic meaning of the staff from an analytical psychological perspective. The symbol of the staff may be seen as the world tree, as an axis connecting God and man. This is the driving force of individuation, which integrates human unconsciousness and consciousness while discovering and accepting the genuine Self. Humans realize Self through consciousness of the inner personality by constantly establishing a relationship with the inner world of unconsciousness. They desire to constantly communicate with God, and they want to live a symbolic life through transformation. As a spiritual guide, the staff is an archetype of the therapist. It also contains the meaning of the world tree praying for unity with God in the process of human personification. This study analyzed the staff that has transformed from alchemy to spirit, the staff that symbolizes the call of God in religious terms, the staff of the resurrected symbol that was reborn as the world tree, and the individuality realized through the symbolism of the staff. The symbolic meaning of the staff as a spiritual guide is an indicator of individuation that is constantly reborn by transformation and reproduction.
\end{abstract}

Keywords : staff, symbolism, axis mundi, ego-self axis, individuation

* Corresponding Author: Ph.D. student, Department of Child Welfare, Namseoul University \& head counselor, Solparan Institute for Children (bhso2002@hanmail.net) 
Journal of Symbols \& Sandplay Therapy, Vol.9 No.2.

\section{I . Introduction}

The staff has been around since the beginning of mankind. It is one of the meaningful tools that humans have made. The staff is mostly known as a tool for the elderly with mobility difficulties but we can hardly see them lately, except for the white staff for the visually challenged. Our ancestors used the staff as a mobility assistance tool or a defensive weapon, such as the staff for a Korean A-frame, the staff of a monk or a guru who lives in a mountain. Thus, the staff contains symbolic meanings besides its practical function.

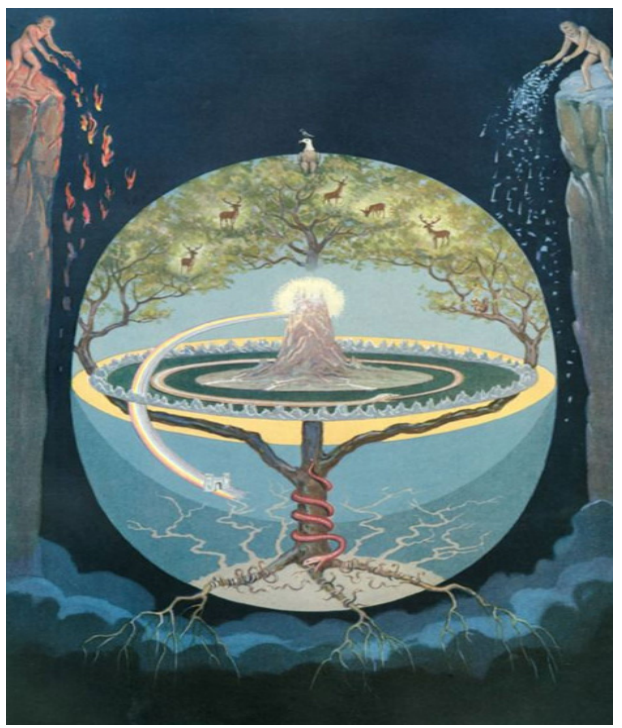

Figure 1. Yggdrasil

The mythology of the North Germanic peoples is called Norse mythology. The world of Norse mythology consists of an endless sea which is fashioned by the blood of Ymir and surrounded by infinite fog. In the middle of the world is a huge circular earth, and beneath the earth exists Svartálfaheimr, the home for black elves. Jornungander, the great World Serpent, surrounds the earth, with his tail in his own mouth. Under the sea or on a distant exists the golden palace of Egir, the god of the sea. Yggdrasil, the immense ash tree, represents the cosmic tree or the world tree.

http://blog.naver.com/PostView.nhnblogId

The most common symbolic meanings of the staff are social status and authority. It represents masculine power, authority and dignity and has the same symbolism with khakkhara (Cooper, 1978/1994). In Western Europe, an aristocrat or a commander may hold the staff as a symbol of authority. The Quechua who live along the Andes have the staff called "barra," which is carried by the high-ranking positions. In ancient Egypt, kings carried a scepter. A Buddhist monk's staff, a Xian's staff in China and a wizard's wand in Europe also represented 
the owner's social position or job. The cane, a staff with a curved or round top, has been known as a symbol of power, authority and social prestige. The staff was and is used to represent a leader's authority. In medieval churches, the staff represented one's official authority, i.e., one's dignity and jurisdiction. As such, the staff was a highly symbolic tool in ancient society and was the symbol of monarchs or monks in the Middle Ages (Hanguksajeonyeongusa, 1998).

In addition, the staff has a symbolic meaning of supernatural power. In the Old Testament, the staffs of Moses and Aaron are the evidence of God's authority given to them. In Andean cultures, the Staff God is a major deity for thousands of years. In East Africa, the staff of the Teso woman was believed to have power to make woman pregnant. The staff also appears in the birth myth of the Inca Empire. According to the myth, the Empire's first king threw his golden staff and found the land for his capital (Kim, 2015).

A shepherd's crook represents authority, guidance, jurisdiction, mercy, faith and is an appendage to all the good shepherds. In the Ancient Near East and Babylonia, a shepherd's crook was one of the signs of a king. In Egypt, the king is regarded as a shepherd who guides and raises the nation and thus king's scepter is the shepherd's crook. In Christianity, a shepherd's crook represents the staff of the good shepherd Jesus and the apostles, and also an appendage to a pastor as the guide of believers (Cooper, 1978/1994).

Some of the ancient Egyptian gods have uniquely shaped staffs. Messenger gods like Hermes (Mercurius) or the god who guides souls to another world and has them tried are usually depicted with a staff in their hand. In Egypt, a crook is an appendant to Osiris, the god who judges the dead (Cooper, 19788/1994).

On the other hand, there are staffs with magical power: wands. As an appendage to all the wizards, shamans and sorcerers, a wand symbolizes magical power and supernatural forces. The staff of Hypnos, the god of sleep, has a power to bring sleep and oblivion (Cooper, 1978). The magical power of a wand has long been a subject of movies. In Harry Potter movies, wands are made of holy wood. Also, the Gaels make a magical "white wand" from the wood of the yew tree, which symbolizes immortality and magical power (Cooper, 1978/1994). 
Journal of Symbols \& Sandplay Therapy, Vol.9 No.2.

As described above, staffs have various symbolic meanings depending on their type. Such archetype inherent in the collective unconsciousness of the human psyche contains strong affection. The symbolic meanings of an archetype cannot be fully described in words. A symbol is significant as it projects the archetypal energy and resolves or unites the tension between the opposites that causes emotional difficulties (Kim, 2011).

The staff has been used as a symbol connecting the land and the spirit, and also men and god. This is consistent with the idea that the sacred power of the staff represents the axis mundi or the cosmic axis that penetrates the earth and the sky (Cooper, 1978/1994). According to Eliade, trees symbolize the axis mundi, thus a staff made from wood has a transcendent power to deliver the energy of the axis mundi to the earth. As tree roots extend deep underground while branches reach up to the sky, many ethnic cultures regarded them as the axis mundi that connects the earth and the sky, or defined them as the "symbolism of a center." The most representative concept of the axis mundi is Yggdrasil, an immense mythical tree in the Norse mythology. Yggdrasil represents the cosmos that is ceaselessly reborn from death but only to return to it (Eliade, 1949/2003). The tree contains abundance and divinity, the infinite sources of the cosmic life. In other words, the world tree connects god in the sky and men on the earth. The human drive to connect to god is a drive for individuation.
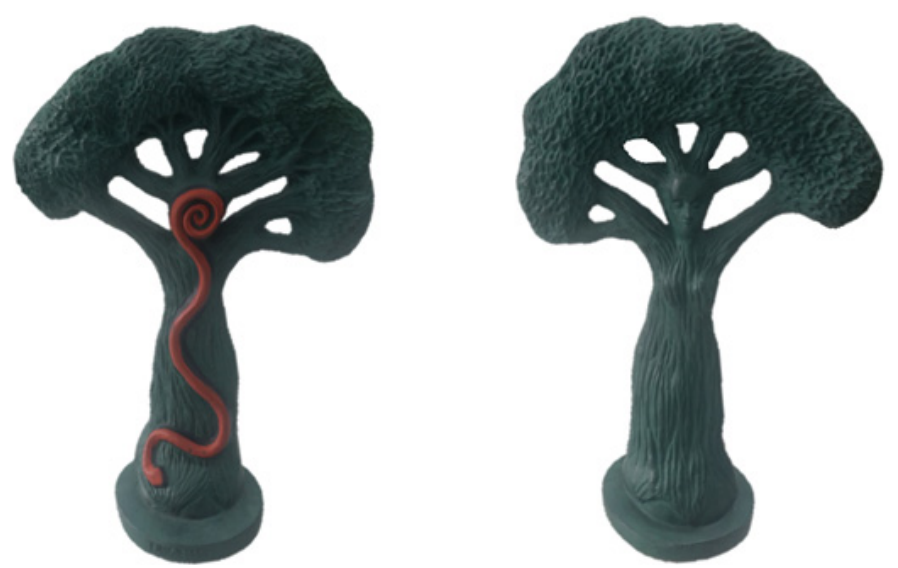

Figure 2. Trees as a symbol of the world tree http://www.sandplay.or.kr 
Sometimes trees represent the ego-Self axis. This axis makes it possible for the ego and the Self to communicate with each other, and only through this communication can desire and impulse for life be brought from the Self (Kast, 1992). Hence trees are a symbol of individuation, and so is the staff.

In therapy, we often witness clients who mention the staff by talking about their dreams or show a staff image during sandplay therapy. A depressed woman in her late forties experienced healing energy through a dream where she held a staff with a green snake coiled around it. Through the staff, she experienced a positive transformation and embarked on the individuation. Individuation is a process where a one unites the unconscious and the conscious, and hence discovers and accepts their genuine Self. As the ego continuously engages in a relationship with the inner world of the unconscious, it becomes conscious of the inner personality and thus we are able to discover our genuine Self. Human beings depend on an absolute being with desperation when faced with pains in life. They long to communicate with god and strive to live a symbolic life through transformation. This is the path toward individuation.

In the individuation process, the staff as a symbol of the world tree that invokes union with god is a spiritual guide and a passage. Here, the word "spiritual" refers to the world of the psyche connecting to the realm of divinity, or the concept of reaching the Self through experience of connecting to a greater being (Waaijman, 2002).

This paper thus explores the symbolism of the staff from the viewpoint of analytical psychology and examines the significance of this archetype energy in the individuation process.

\section{П. Symbolism of the staff}

\section{A. Staff as the Healer Archetype}

The symbol of the healer archetype can be seen in gods of medicine in many mythologies. For instance, it can be found in Asclepius in Greek mythology, Samseung 
Journal of Symbols \& Sandplay Therapy, Vol.9 No.2.

Halmang and Baridegi in Korean folktales, the greatest being of various religions such as Christ, Buddha, the Jade Emperor and Odin in Germanic mythology They connect the world of the living and the world of the dead, and guide souls to the world of the dead. They are also important teachers for human beings in their initiation into the adulthood. They observe human asceticism and help humans to move up to a more mature level of life though the process (Lee, 2003).

In Greek mythology, the rod of Asclepius is a serpent-entwined rod wielded by Asclepius, god of medicine and son of Apollo. As Apollo gave Asclepius the gift of healing and the secrets of medicine, Asclepius could even bring the dead to life. Hades, the ruler of the dead, became angered by this and Zeus eventually killed Asclepius with his thunderbolt. After his death, Asclepius was revered as the god of medicine. Many snake figures can be seen in his temples. Regarded as mysterious animals, snakes were revered as spiritual animals that are aware of the life force or secrets of the Earth. And because snakes shed their skin through sloughing, they are a symbol of wisdom, rebirth and healing. In Greek mythology, snakes symbolize both death and regeneration. Like Jonah in the Bible, Jason, an ancient Greek hero, was swallowed by a giant snake but got out after three days. Hercules was also swallowed by a serpent but he punched his way out of its stomach three days later. Greek mythology well describes the symbols of the mediator between the two worlds, things that circulate, and things that come around. The symbol of death, the symbol of regeneration and the symbol of the mediator between this world and the world of the dead are not three different things: they are three aspects of the same thing.

This is the reason why the emblem of medicine uses the staff and snake. Records show that the ancient Greek used snake venom as a remedy and let a snake crawl around the patient as a shamanistic treatment. In this regard, the combination of medicine and snake is not so strange. The staff of Hermes in Greek mythology named the caduceus features two snakes winding around it. It symbolizes Hermes, the god of messengers, and it is also a symbol of those Hermes protects: merchants, gamblers, thieves, shepherds and a talisman of the dead. Among staffs, the staff of messenger symbolizes the axis mundi through which the messenger travels between the sky and the earth. The messenger carries the staff as a symbol 
of peace and protection and it is his most important appendage (Cooper, 1978/1994). Hermes can put the living to sleep with his staff and travel between the worlds as he pleases as the messenger of Zeus. His staff features two snakes winding up around its body. According to the myth, Hermes stopped two fighting snakes with his staff and they entwined themselves about the staff. Hermes is called a "psychopomp" or the guide of souls. The wings at the very top of the caduceus represent transcendence and the air, while the stick part of the staff represents power. The entwining snakes are a symbol of the opposites, which are to come into a union eventually (Gerold, 2000/2001).

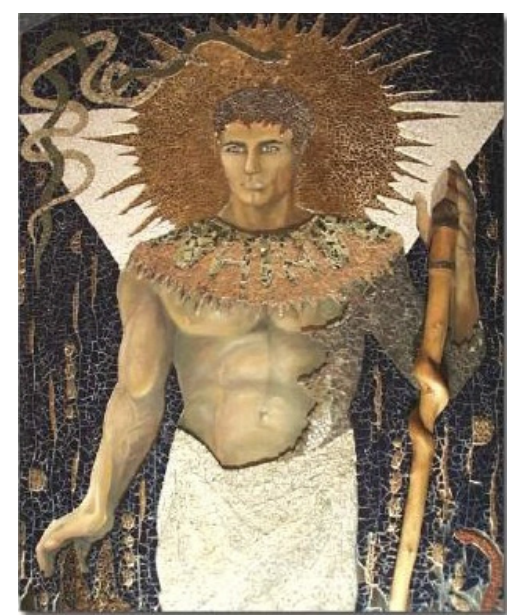

Figure 3. Asclepius, a god of medicine http://blog.daum.net/ceta21/10102266

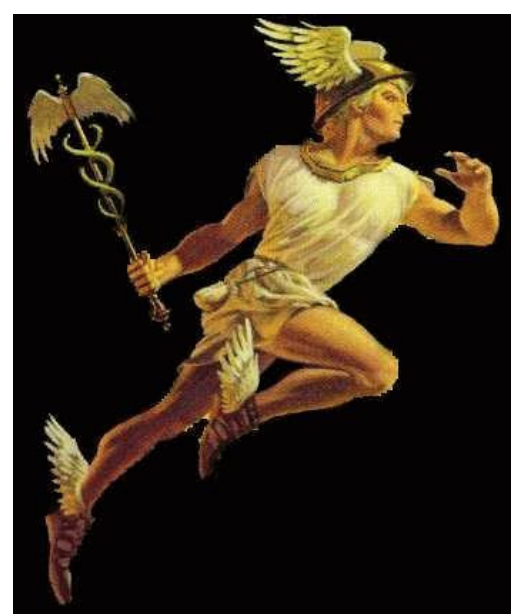

Figure 4. Messenger Hermes http://www.inven.co.kr/board

In Exodus 15:22-27 talks about the story of Marah's water. Marah is the first camp of the Israelites since the passage of the Red Sea. The name is derived from the bitterness of the water. After Moses made Israel set out from the Red Sea, they went into the wilderness of Shur. They went three days in the wilderness and found no water. When they came to Marah, they could not drink the water of Marah because it was bitter. The people grumbled against Moses, and so he turned to God. The Lord showed him a log, and Moses threw it into the water, and the water became sweet. Because humans desperately looked for God with an obedient attitude, the water turned sweet. God said, "I am the Lord who heals you." As a 
Journal of Symbols \& Sandplay Therapy, Vol.9 No.2.

healer, he purified the bitter water. This holds a great significance. In ancient days, doctors were rare and medical practices were not advanced enough and hence it difficult to cure a disease. In this regard, the story holds a symbolic meaning that the sweet water would not only heal sickness but also guide the struggling Israelites to a life of eternity. For that reason, the place is sometimes called the "Well of Moses." The story shows that a $\log$ can be a healing tool to save many lives once God breathes the spirit of life into it.

\section{B. Staff as a Symbol of Spiritual Transformation}

The staff of Mercurius (Hermes) was also used as a key symbol of alchemy in the Middle Ages. In alchemy, the two snakes represent the masculine sulfur and the feminine mercury, reproductivity, sleep and awakening. In the "Great Work," the staff represents a transcendent function that mediates dissolution and coagulation, the opposites, heaven and hell. The staff was the core ingredient to create gold and the homunculus (Cooper, 1978/1994).

Mercurius was inserted as an illustration in an alchemy book from the 15th century. The staff with snakes in his hand symbolizes the union of the opposites. The ideal materialization of such union is Mercurius himself (Cooper, 1978/1994). Mercurius is the divine winged Hermes manifest in matter, the god of revelation, the king of darkness, and sovereign psychopomp. Mercurius with a staff in his both hands represents the union of the opposites, i.e., the earthly principles of the serpent and the aerial principles of the bird, or Sol and Luna (Jung, 1985/2004b). Mercurius stands at the beginning and end of the work. Mercurius is the prima materia, the first matter, or the inflated psyche which must be transformed into the philosopher's stone or the spiritual element (Edinger, 1972/2016). The prima materia is our ego-Self identity, the residue of original inflation. To submit the prima materia to the alchemical process means to apply conscious effort and attention to the task of refining and separating this composite mixture to the end that the Self will be freed from its contamination with the ego. (Samuels, 2000/2004).

Mercurius devours himself and dies, to rise again as the lapis. $\mathrm{He}$ is the hermaphrodite that was in the beginning, that splits into the traditional brother-sister duality and is reunited in the coniunctio, to appear once again at the end in the radiant form of the 
lumen novum (new light), the stone. He is metallic yet liquid, matter yet spirit, cold yet fiery, poison and yet healing draught - a symbol uniting all opposites (Jung, 1985/2004b).

Wings at the top of the staff represent transcendence and the air, and the staff represents power. The entwining two snakes symbolize a pair of opposites that are eventually united. The snakes around the staff symbolize the spiral circulation of the nature, summer/winter solstice, rolling and unrolling, dissolution and coagulation in alchemy (Gerold, 2000/2001).

Moses' staff, which transformed into a snake and back to its original state, represents dissolution and coagulation in alchemy (Cooper, 1978/1994). "The Lord said, 'Throw it on the ground.' Moses threw it on the ground and it became a snake, and he ran from it. Then the Lord said to him, 'Reach out your hand and take it by the tail.' So Moses reached out and took hold of the snake and it turned back into a staff in his hand" (Exodus 4:3-4). As Moses reached out and took the snake by its tail on God's command, it was transformed back to a staff. It symbolically shows the transformation of a basic matter into "spirit" in order to free a soul. The alchemical process brings about psychic transformation, not material transformation.

\section{Staff as a Symbol of Divine Calling}

In the Book of Exodus, Moses performed many miracles with his staff to liberate the Israelites from slavery. As Moses followed God's calling, his trifling staff became a medium to display God's power, working miracles. In other words, Moses' staff was a spiritual guide in the journey of the Israelites to the Promised Land.

For the first 40 years, Moses had enjoyed a life of wealth as a prince of Egypt. However, he chose a difficult life to be on the side of those in need, giving up his comfortable life (Lang, 2005/2007). So he spent the next 40 years on a journey of tribulation as a shepherd in Midian. But after he turned 80, God called upon him to set free the Israelites enslaved to Egypt and guide them to the Promised Land. Here, the shepherd's crook in the hand of Moses is reborn as a spiritual tool empowered with God's authority. This crook symbolizes Moses' calling to lead the Israelites to the Promised Land as a spiritual guide for the next 40 years. The individuation process of Moses was not easy. It was a journey of 
Journal of Symbols \& Sandplay Therapy, Vol.9 No.2.

meeting his genuine Self after an intense experience of alienation, as explained by Edward Edinger.

The inner struggle for individuation is presented in the collective unconscious in the story of Moses, and it can be completed only when accepting God's choices and plans. In the Bible, the staff of Moses is a spiritual tool that guides the Israelites to miracles and life, and a medium that works God's miracles. When the Israelites grumbled that there was no water to drink, Moses struck the rock at Horab with his staff and water gushed out for people. In addition, he parted the Red Sea with his staff. He guided the Israelites in a crisis, who were just helpless in front of death, to the path of rebirth and life. This staff resolved human conflicts as a spiritual medium to prove God's sanctity. Moses showed characteristics of a mythological hero by carrying out miracles, and his staff represents God's authority. God's divinity presented in Moses' staff materializes only when our body and soul desperately want to be close to Him. In short, God's divinity presents itself only when we embrace our imperfections and take a step closer to Him.

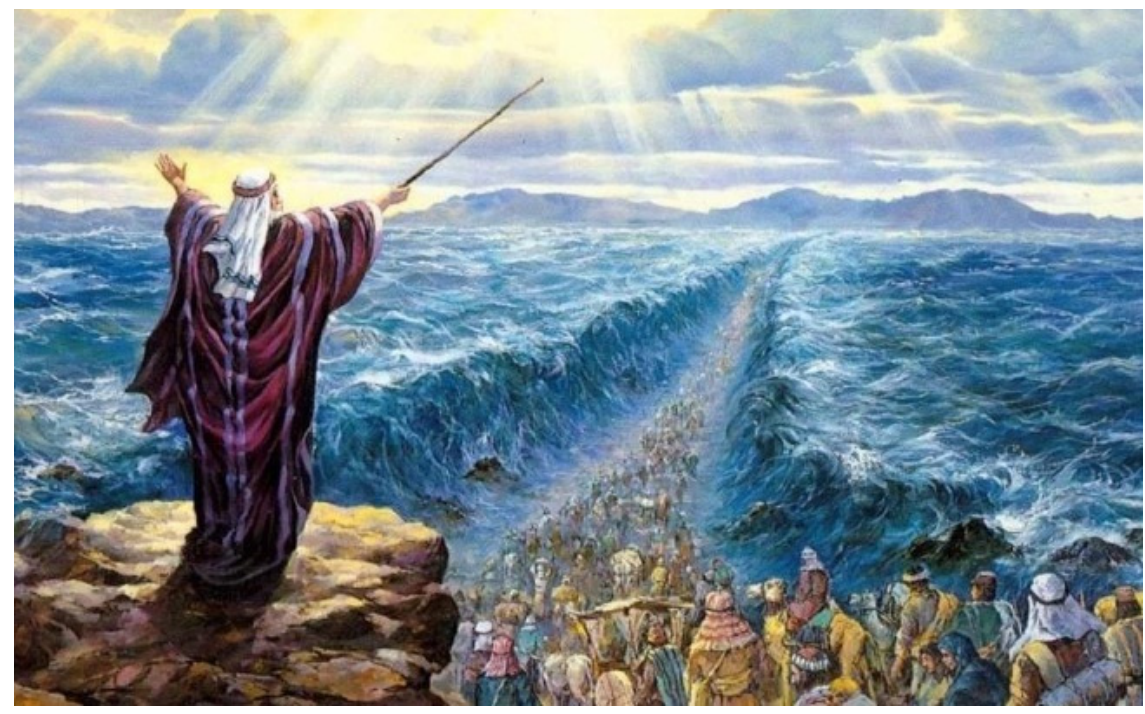

Figure 5. Moses' staff empowered with God's authority http://blog.naver.com/akgo33 
Moses' calling resembles that of Gandhi, the spiritual father of India. Moses and Gandhi are spiritual guides for those who are alienated in the face of injustice, leading them to the life of eternity. Great people who accept God's calling and lead the change end up experiencing God in any form. To experience God is to step into the path of individuation, i.e., self-realization. Those who have embraced their calling come to experience the process of discovering the Self in their life. Self-realization always entails countless hardships and steps to overcome them. Many mythological heroes had to train themselves ceaselessly to be born again. According to Jung, personality transformation can be gained only after experiencing trials over a long period of time. Those who have looked back their mundane life and purified their inner world through individuation can see God more clearly (Kim, 2001).

\section{Staff as a Symbol of Rebirth, Reborn as the World Tree}

The world tree, also called the cosmic tree, is a tree present in birth myths and folk religions around the world. It is a divine tree that connects the heaven and the terrestrial world. Yggdrasil (the ash tree) in Norse mythology, the Huluppu Tree (the willow tree) in

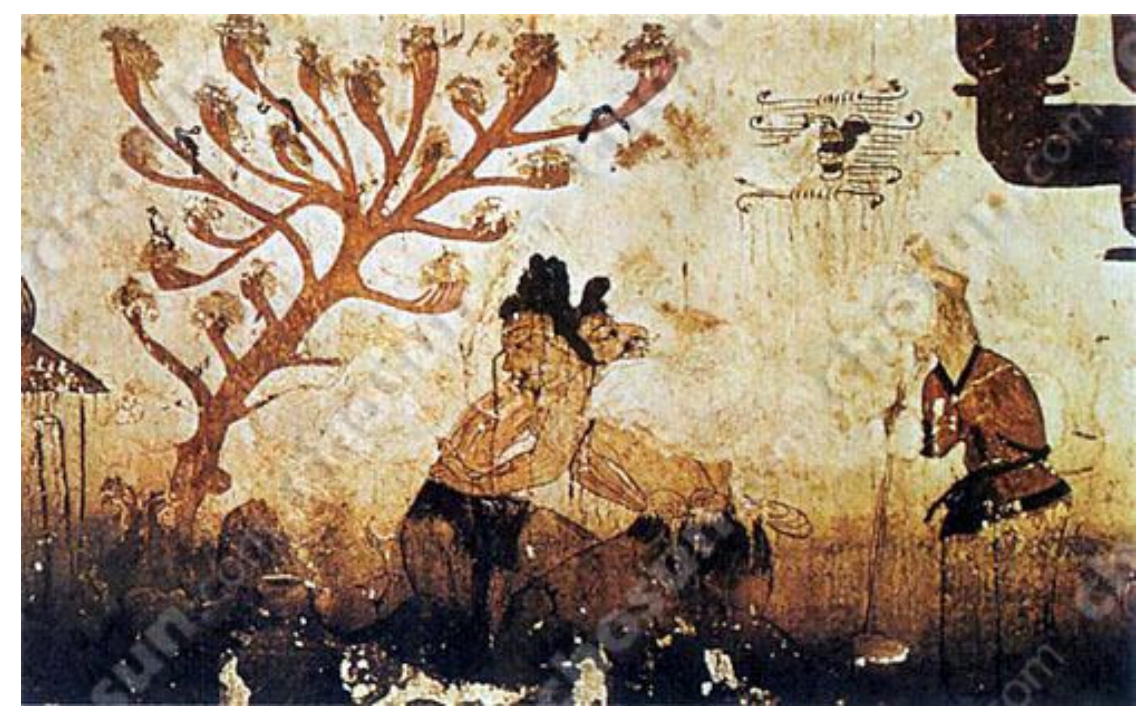

Figure 6. The world tree in "Ilwolbusangdo," a tomb mural of the Koryo Dynasty http://blog.naver.com/silvino111 
Journal of Symbols \& Sandplay Therapy, Vol.9 No.2.

Sumerian mythology and Shindansu (the birch tree) in Dangun mythology are examples of the world tree. In Korea, the world tree was present in "Ilwolbusangdo," a folk painting of the Joseon Dynasty, and also the tomb murals of the Koryo Dynasty, which shows that ancient Koreans believed that the world tree connects god and men (www.forest.go.kr).

The tree's vitality, immense size and regenerability represent the cosmos that endlessly regenerates or the source of eternal life. Among many natural objects, people have revered trees since the ancient times because of the unique characteristics inherent to trees. Such worshiping gave birth to divine trees, such as the world tree or the Tree of Life. The Tree of Life is usually located at the center of the Garden of Eden and represents regenerability and a return to original integrity. The Tree of Life is the axis mundi and a unitary being transcending good and evil. The Tree of Life also represents both the beginning and the end of a cycle (Eliade, 1949/2003).

The world tree is connected with the idea of the center of the world. The world tree stands at the center of the world, connecting the heaven and earth. Not only in the Vedic Period of India but also in ancient China, Germanic mythology and primitive religions, the tree is known to have roots reaching the hell and branches the heaven. It can be seen as a kind of a pillar or an axis, allowing the communication between the heaven and earth.

The world tree has been around in many forms. A staff with flowers or buds also represents the world tree as axis mundi. The axis mundi is the central point between time and space, the highest point that all creation supports, the axis around which all creation revolve, rules and the essence of all creation (Cooper, 1978/1994). According to Jung, the world tree as the axis mundi represents the energy of life, the individuation process and the Self. Trees also have the power to produce, and can represent God's body in its entirety (Lee, 2003).

The rod with buds of Aaron, who became the first high priest of Israel, is a symbol of the world tree. After Korah's rebellion against Moses and his brother Aaron, who was selected as high priest, God told the heads of twelve tribes of Israel to bring an almond rod and put them in the "tabernacle of witness" to show them his appointed high priest. When they came the next day, they found no changes in their rods but the rod of Aaron for the tribe of Levi brought forth buds, bloomed blossoms, and yielded almonds. After this, the 


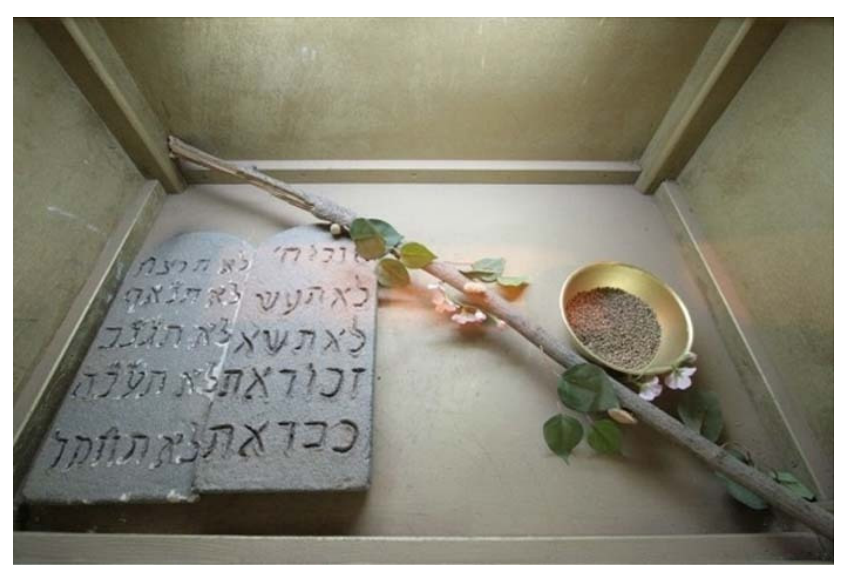

Figure 7. Aaron's staff with buds kept in the tabernacle of witness https://cafe.daum.net/ymcdeat

Israelites conceded that God chose Aaron as high priest and the tribe of Levi as his servants (Yoo, 2008).

The common Hebrew name for apricot is shaqed, which comes from a root meaning "to be awake and watching." Apricot blossoms and apricot represent that God chose Aaron and his direct descendants as high priest, and God is awake to protect Israel. By making the lifeless rod blossom, God showed the legitimacy of Aaron's priesthood. Resurrection is premised on death. The rod in this story is different from a branch. A rod is dry and lifeless. That the lifeless and dry rod budded, blossomed, and yielded apricots represents rebirth. It signifies regaining life from the source of life. A true sense of life gives birth to another life, like the lifeless rod that blossomed and yielded fruits (Yoo, 2008).

To be born again, people must first go through a spiritual death. According to Jung, "spiritual death" or la moet spirituelle comes only after psychic sacrifice. Infantility ought to be sacrificed while a new source of life, different from the mother's breast, should be found (Kim, 1998). To sacrifice means to abstain or to give up. However, the original meaning of sacrifice is to sanctify. Sacrifice is a price to pay for the "conscious" (Samuels, 2000/2004). For a new Self to be born, one needs to confront with, struggle against, sacrifice and overcome the opposites. By doing so, the opposites can ultimately come into a union.

Stories about a dried lifeless rod that budded can also be found in Korean folktales. 
Journal of Symbols \& Sandplay Therapy, Vol.9 No.2.

The cottage motif that a staff planted in the ground grew as a tree is originated from the cottage mythology and found all across the world. There is story with a cottage motif in Korea as well.

Flowers called sunbiwha (caragana sinica) are still found in Buseoksa Temple, located in Yeongju, North Gyeongsang Province. These flowers grow under the eaves of Josadang and are known to be originated from Great Buddhist Priest Uisang's staff that budded. The story about this staff dates back far into history. After Great Buddhist Priest Uisang, the founder of Buseoksa Temple, stuck his staff into the ground for the people, the staff budded and bloomed. When he entered into Nirvana, he foretold, "Stick this staff into somewhere that it won't get wet from rain or dew. When the staff buds and blossoms, the nation will flourish." Later, the staff that was planted in the embankment of Josadang budded and yellow flowers bloomed. Since then, the staff always budded and blossomed whenever the nation flourished and was at pace. However, it never blossomed during the Japanese colonial era. Then it blossomed 30 years later when Korea became independent from Japan. The tree's age is estimated at 1,300 years but it is only 130 centimeters tall, without growing much from the past. What makes the flowers even more mysterious is that they are always fresh even though they grow under the eaves and thus are not exposed to rain or dew. Some people believe that a sterile woman can give birth to a boy if she drinks the water in which the sunbiwha petals are boiled (Kim, 2007). This folktale is another story depicting the world tree's symbolic meanings of endless life and new birth.

Every mythology and folktale represents the psychological process of the collective conscious. A Jungian psychologist Marie-Louise von Franz claimed that all the folktales represent the Self, the core and ultimate destination of one's personality, in various ways (Kim, 1998). The Self is the center of the psyche that includes both the conscious and unconscious, and it is a central archetype among all archetypes. It is also the source of energy for individuals, and the creative principle that stimulates and guides the structuralization of the ego complex. Once connected to the Self energy, individuals can experience a deep, awe-inspiring and mysterious energy. They can also feel that they have a very special (i.e., divine) strength, and that they are connected to a bigger whole (Jang, 2017). 
The symbolism of the staff that reborn through transformation can also be found in the field of music. Jung explained that all the works of art are greatly affected by not only the creator's psychology but also the things that belong to the collective aspect of human psyche (Kim, 1998).

A staff that is reborn through atonement and transformation is a subject of Wagner's opera "Tannhäuser." In Medieval Germany, there is the minstrel knight Tannhäuser, a lover of Elizabeth who is a niece of the Landgrave Hermann. He has been enjoying worldly pleasures in Venusberg, the realm of the goddess of love Venus. However, he gets weary and goes back to the human world. One day, in a song contest, he sings in praise of Venus and sensual love. The other knights and the Landgrave gather to condemn Tannhäuser to death but Elisabeth intervenes and begs them for mercy. Tannhäuser is ordered by the Landgrave to make a pilgrimage to Rome to seek penance from the pope. The pope's staff buds if a man achieves salvation through atonement, but it doesn't buds for Tannhäuser. Elizabeth dies in despair, thinking that Tannhäuser failed to reach salvation. During Elisabeth's funeral, Tannhäuser also dies by her bier. At that moment, younger pilgrims arrive bearing the pope's staff sprouting new leaves. It means Tannhäuser has gained absolution (Johnson, 2007/2012).

\section{E. Realization of Individuation through the Staff's Symbolism}

One of the spiritual meanings of the staff is spiritual energy that generates strength with sacred desire, when faced with darkness of disorderly and chaotic life. When one truly realizes it and accepts it, the staff leads them to self-realization as a spiritual guide. It brings in change of consciousness in human life. The moment we realize this, we can set a new direction for our lives going forward, i.e., embark on a path toward individuation.

Influence by Jung's theories, Edinger explained the individuation process through the model of the ego-Self axis. The staff, like Jacob's ladder in the Bible, symbolizes the ego-Self axis. The ego is in a state of inflation when it identifies itself with the Self, and when it experiences extreme alienation when separated from the Self. This cycle repeats itself throughout our psychic development. In the individuation process, particularly in the latter part of life, developing the ego-Self axis is an important task. This task emphasizes the need for a deep 
Journal of Symbols \& Sandplay Therapy, Vol.9 No.2.

connection between the ego and the Self. With the development of the ego-Self axis, the ego is not abandoned but actually develops a more mature attitude.

Individuation is a process in which the ego becomes mature. It is a process where innate personality factors, various life experiences and immature psychic factors integrate as a whole over a long period of time. Jung called this spiritual transformation self-realization, or the state of wholeness. Human beings have an innate desire for divinity, which is the movement toward the wholeness or the individuation process. However, a complete individuation is utopian; it is impossible to achieve individuation to its perfection regardless of an individual's intentions (Jang, 2017).

Individuation, or the journey toward wholeness, is not easy. This journey is not a straight path, but a serpentine path that connects the opposites; it is the "longest path." Human beings can't experience wholeness without experiencing the opposites. This reminds us of the caduceus, the staff of Hermes, which will guide the way made of detours and wrong turnings. "Inaccessible experiences" can be achieved on this path (Jung, 1985/2002).

One will face countless conflicts on the way to the Self through the union of the opposites. When a person meets the Self that unites opposite elements in the inner world, that person is said to have reached individuation or self-realization (Jang, 2010).

Individualization differentiates and integrates numerous elements that constitute the psyche. Through individuation, we become an undifferentiated "self" by becoming connected to the "Self," the center of the psyche. To that end, the ego must first move away from identifying itself completely with the persona, and willingly accept the shadows, which are a part of ourselves that we refuse to recognize for their negative characteristics. Most people do not recognize their shadows, and even those who do suppress them. And while doing so, they look for those shadows from others. Such projection can leads to various wounds and conflicts in our lives. When we accept the existence of the shadows and accept them as part of our nature, we can become whole. Instead of projecting inferior, imperfect or negative elements inside us onto other people, we ought to recognize and integrate them as part of ourselves.

Individuation occurs when we understand what whole life is and allow part of ourselves to become god. In other words, we become saints who take responsibility for their 
existence, realizing that humans seek to communicate with god. Our personality transforms through this process. For that reason, just as Jung said, individuation cannot be achieved at once but is a goal to be achieved over one's lifetime. The process continues in a spiral until the day we die; it is the course of life that we should take.

\section{Conclusion}

Symbols contain the archetypal psychic energy, and thus they are still very much alive and breathing, transcending times. Dating back to ancient times, symbolic images are constantly generated in the unconscious of people in modern society. If we willingly accept the flow of the symbolic energy, it brings changes that will help us reach a new form of positive life. The Self represents itself and grows through symbols. Symbols deliver energy that consciously or unconsciously supports, guides and motivates individuals to the ego (Einder, 1972/2016).

The power of human unconscious manifested through symbolic meanings can be observed not only in clinical settings but also in myths, religions, arts and all other forms of self-expression. In short, the work of uniting the unconscious and the conscious is the individuation process.

Individuation process with an objective for self-actualization represents the dynamic aspect of the Self archetype. When the energy of the Self archetype and the ego are connected, the individual as well as the system based on which one operates undergo a change. The only way to attain a healthy life is to discover one's true individuality and Self, which is completely alienated by the ego as one conforms to social demands unconditionally. In other words, healthy life can only be attained through individuation. In this regard, individuation is a healing process, or a process that makes people healthy (Jung, 1964/2013).

Individuation can be achieved by realizing the wholeness of the psyche, which includes the conscious and the unconscious. Opposites can be united when we recognize the symbolisms of the cosmic axis or the ego-Self axis contained in the staff. On the path to individuation, 
Journal of Symbols \& Sandplay Therapy, Vol.9 No.2.

one can take a step forward by embracing the symbolism of the staff as a spiritual guide.

Reaching individuation is very difficult. Having reached individuation means to untie countless opposites and hence be reborn as a completely different being from the past. It is an experience in which the Self, the center of the psyche, meets the source of our personality and is born anew. During this process of union, constant transformations take place. Jung explained that through initiation it is homo totus whom we seek, that hidden and as yet unmanifest "whole" man, who is at once the greater and the future man (Jung, 1985/2004b). He said that if we direct our psychic energy focused outside to the inner world, we will obtain an image that helps us integrate our lives and guides us to a higher level. Thus, we need to engage in a constant communication with our inner world.

The staff, which is reborn ceaselessly through transformation and regeneration, symbolizes a spiritual guide. It is a tool necessary for the individuation process which aims to realize the Self.

\section{References}

Kim, S-M. (1998). Jung's psychology and religion. Seoul: Dongmyeongsa.

Kim, S-M. (2001). Analytical psychology and christianity. Seoul: Hakjisa

Kim, S-H. (2007). Temple originated narrative read through cultural heritage: Along temple, along legend. Seoul: Daewonjeonsa.

Kim, E-S (2011). Hawk. Journal of Symbols \& Sandplay Therapy 2(1), 15-28.

The presbyterian church of Korea (2015). The book of Exodus. Seoul: Korean Presbyterian publisher.

Yu, D-G (2008). Numbers. Seoul: IMC.

Lee, B-Y. (2003). Analytical psychology; C. G Jung's thoughts on mind. Seoul: Ilchoak.

Lee, B-Y. (2004). Self and self realization. Seoul: Hangilsa.

Lee, Y-Y. (2004). Archetype and myth. Seoul: ECLIO.

Jang, D-G. (2010). Mid-life crisis and Jung's theory of individuation process: Life of Jacob and 
Moses. University of Hyup Sung Master's Paper.

Jang, M-K. (2017). Analytical psychological sandplay therapy. Seoul: Hakjisa.

Korean Dictionary Research Publishing (1998). The great encyclopedia of religions science.

Seoul: Korean Dictionary Research Publishing.

Kim, K-P, Jemin Daily News column. 2015.8.3.

Cooper, J. C. (1978). An illustrated encyclopedia of traditional symbols. New York: Thames \& Huson. (Trans. into Korean in 1994)

Eliade, M. (1949). Le mythe de i'eternel retour. Paris: Edition Gallimard. (Trans. into Korean in 2003)

Einder, E. (1972). Ego and archetype: Individuation and the religious function of the psyche. Boston: Shambhala. (Trans. into Korean in 2016)

Gerold, D. G. (2000). 50 Klassiker Mythen. Gerstenberg: Verlag. Hildesheim. Germany. (Trans. into Korean in 2001)

Johnson. S. (2007). Wagner his life and music. New York: Music \& Letters. (Trans. into Korean in 2012)

Jung, C. G. (1964). Man and his symbols. London: Aldus Books. (Trans. Into Korean, 2013)

Jung, C. G. (1985a). Erlösungsvorstellungen in der Alchemie. Olten: Walter-Verlag. (Trans. into Korean in 2004)

Jung, C. G. (1985b). Traumsymbole des Individuationsprozesses. Olten: Walter-Verlag. (Trans. into Korean in 2004)

Jung, C. G. (1885). Gegenwart und Zukunft. Olten: Walter-Verlag. (Trans. into Korean in 2013)

Kast, V. (1992). The dynamics of symbol: Fundamentals of Jungian psychotherapy. New York: Fromm International.

Lang, S. (2005). Bible key word. Ohio: Writer's Digest Books. (Trans. into Korean in 2007)

Samuels, A. (2000). A critical dictionary of Jungian analysis. New York: Routledge \& Kegan Paul. (Trans. into Korean in 2004)

Waaijman, K. (2002). Spirituality: Forms, foundation, methods. Brussels: Peeters Pub \& Book sellers 
Journal of Symbols \& Sandplay Therapy, Vol.9 No.2.

http://blog.daum.net/ceta21/10102266 Asclepius, a god of medicine http://blog.naver.com/PostView.nhnblogId

http://blop.naver.com/akgo33 Moses' staff empowered with God's authority

http://blog.naver.com/silvino111 The world tree in "Ilwolbusangdo," a tomb mural of the Koryo

Dynasty

https://cafe.daum.net/ymcdeat Aaron's staff with buds kept in the tabernacle of witness

http://www.inven.co.kr/board Messenger Hermes

http://www.sandplay.or.kr Trees as a symbol of the world tree

www.forest.go.kr.

Received : October 30, 2018

Revised : December 5, 2018

Accepted : December 27, 2018 